\title{
Immunocytological diagnosis of primary cerebral non-Hodgkin's lymphoma
}

\author{
A P Lai, A S Wierzbicki, P M Norman
}

\begin{abstract}
Four men with primary cerebral nonHodgkin's lymphoma diagnosed by immunocytological analysis of cerebrospinal fluid (CSF) presented with cranial nerve palsies. All had CSF lymphocytoses and low CSF glucose. The cell phenotypes were two $T$ cell tumours, one $B$ cell, and one null. A review of 13 previously recorded cases of immunocytologically diagnosed CNS nonHodgkin's lymphoma showed that there were $10 \mathrm{~B}$ cell, two $T$ cell, and one null tumour. Overall (17 cases) the cell phenotype distribution was $65 \%$ B cell, $24 \%$ T cell, and $11 \%$ null. High CSF lymphocyte counts were found in $94 \%$, proteinosis in $85 \%$, and low CSF glucose in $87 \%$.

In contrast to the $B$ cell tumours, all of the $T$ cell tumours were diagnosed by CSF cytology before being visualised radiologically. It is suggested that all CSF lymphocytes $\left(>5 \times 10^{6} / \mathrm{ml}\right)$ should be immunohistochemically typed to permit earlier diagnosis of CNS nonHodgkin's lymphoma.
\end{abstract}

Central nervous system non-Hodgkin's lymphoma is a rare form of neoplasia whose incidence has risen from $1 \%$ to $2.6 \%$ of cerebral tumours over the past five years. ${ }^{1}$ We present a series of four cases acquired over three years. These comprised $6 \%$ of all tumours diagnosed by cerebrospinal fluid (CSF) cytology.

Case histories

All the patients had been previously healthy and the clinical details of the four cases are summarised below.

CASE 1

A 61 year old man presented with multifocal neuropathy, diplopia, a left sixth nerve palsy and headaches and had signs of papilloedema. Computed tomographic brain scanning showed a left optic nerve and corpus striatum tumour.

CASE 2

A 66 year old man presented with multiple bulbar palsies. A computed tomogram showed a right cavernous sinus tumour, and three months later, a left ileopsoas tumour.
CASE 3

A 17 year old boy presented with an acute confusional state, diplopia, and a left seventh nerve palsy. A computed tomogram showed no radiological abnormality.

\section{CASE 4}

A 64 year old man presented with bilateral sixth nerve palsies and a right seventh nerve palsy. No radiological abnormality was detected.

\section{Methods}

Cerebrospinal fluid was obtained by lumbar puncture and two CSF cytospin preparations were prepared and stained by the Romanovsky method and the remainder were stained by standard immunocytochemical techniques after a provisional diagnosis had been made. ${ }^{1}$ The antibodies used in the lymphoma panel were anti-Ig, anti-HLA-DR, anti-CD3, antiCD5, anti-CD10, anti-CD19, anti-CD25, and anti-CD45. Two separate positive specimens were required for a diagnosis to be made.

\section{Results}

The CSF biochemical and cytological findings are shown in table 1. CSF biochemistry showed pronounced proteinosis $(19.4-51.0 \mathrm{~g} / \mathrm{l}$; reference limit $10 \mathrm{~g} / 1$ ), and a reduced glucose concentration $(0.2-1.9 \mathrm{mmol} / \mathrm{l} ; \quad$ reference limits 4.5-6.5 mmol/1) in all four cases. All the CSF specimens were hypercellular (230 $830 \times 10^{6} / \mathrm{ml}$; reference limit $\left.3 \times 10^{6} / \mathrm{ml}\right)$ and showed a predominance $(>80 \%)$ of abnormal large malignant lymphoid cells. Results of CSF and blood serology and immunoblots were unremarkable in all cases. In two cases the diagnosis was confirmed by biopsy of the tumour deposit (cases 1 and 2) and in the others by biopsy of later secondary deposits. Histological analysis confirmed the cytological findings of two T cell lymphomas, one B cell and one with null staining on two occasions.

\section{Discussion}

The incidence of primary cerebral nonHodgkin's lymphoma is increasing; $25 \%$ of cases show meningeal infiltration at necropsy, ${ }^{2}$ and some cases have been diagnosed as a result of this by CSF cytology.

Meningitis is the commonest presentation of CNS non-Hodgkin's lymphoma, ${ }^{2}$ but all our four patients presented with cranial nerve 
Table 1 CSF biochemical and cytological details of four cases of CNS-non Hodgkin's lymphoma diagnosed by CSF immunocytology

\begin{tabular}{|c|c|c|c|c|c|c|c|c|c|c|}
\hline $\begin{array}{l}\text { Case } \\
\text { No }\end{array}$ & Sex & Age & $\begin{array}{l}\text { Brain } \\
\text { scan }\end{array}$ & $\begin{array}{l}W C C \\
\times 10 / \mathrm{ml}\end{array}$ & $\begin{array}{l}\text { Lymphocytes } \\
\%\end{array}$ & $\begin{array}{l}\text { Protein } \\
(m g / l)\end{array}$ & $\begin{array}{l}\text { Glucose } \\
\text { (mmol/l) }\end{array}$ & $\begin{array}{l}\text { Morphology } \\
\text { of cells }\end{array}$ & Immunochemistry & $\begin{array}{l}\text { Cell } \\
\text { type }\end{array}$ \\
\hline 1 & $\mathbf{M}$ & 61 & + & 830 & 85 & 30 & 0.5 & $\begin{array}{l}\text { Large cell } \\
\text { cleaved nucleus }\end{array}$ & $\begin{array}{l}\mathrm{CD} 19[+] \mathrm{CD} 3[-] \\
\mathrm{CD} 5[-] \mathrm{CD} 25[-] \\
\mathrm{CD} 45[-] 1 \mathrm{Ig}[+-]\end{array}$ & B \\
\hline 2 & $\mathbf{M}$ & 66 & + & 230 & 90 & 20 & 1.9 & $\begin{array}{l}\text { Large cell } \\
\text { non-cleaved nucleus }\end{array}$ & $\begin{array}{l}\text { CD10[+] CD5[ }[-] \\
\text { CD19[-] CD25[-] } \\
\text { Ig }[-] \text { HLA-DR[-] }\end{array}$ & Null \\
\hline 3 & $\mathbf{M}$ & 17 & $\mathbf{N}$ & 320 & 93 & 48 & $5 \cdot 2$ & $\begin{array}{l}\text { Large cell } \\
\text { non-cleaved nucleus }\end{array}$ & $\begin{array}{l}\text { CD5[+] CD } 3[-] \\
\text { CD19 }[-] \text { CD25[-] } \\
\text { HLA-DR }[-] \mathrm{Ig}[-]\end{array}$ & $\mathbf{T}$ \\
\hline 4 & $\mathbf{M}$ & 64 & $\mathbf{N}$ & 662 & 98 & 51 & 0.2 & $\begin{array}{l}\text { Large cell } \\
\text { non-cleaved nucleus }\end{array}$ & $\begin{array}{l}\mathrm{CD} 3[+] \mathrm{CD} 5[+] \\
\text { CD } 45[+] \text { CD } 19[-] \\
\text { CD25[-] HLA-DR[-] } \\
\text { Ig[-] }\end{array}$ & $\mathbf{T}$ \\
\hline
\end{tabular}

WCC $=$ White cell count; $\mathbf{N}=$ normal

Table 2 CSF cytology and biochemistry details of 13 previously recorded cases of CNS-non Hodgkin's lymphoma

\begin{tabular}{|c|c|c|c|c|c|c|c|c|c|}
\hline \multirow[b]{2}{*}{ Reference } & \multirow[b]{2}{*}{ Sex } & \multirow[b]{2}{*}{ Age } & \multirow[b]{2}{*}{$\begin{array}{l}\text { Brain } \\
\text { scan }\end{array}$} & \multicolumn{6}{|l|}{$C S F$} \\
\hline & & & & $\begin{array}{l}W C C \\
\times 10^{6} / \mathrm{ml}\end{array}$ & $\begin{array}{l}\text { Lymphocytes } \\
\%\end{array}$ & $\begin{array}{l}\text { Protein } \\
(m g / l)\end{array}$ & $\begin{array}{l}\text { Glucose } \\
\text { (mmol } / l)\end{array}$ & $\begin{array}{l}\text { Morphology } \\
\text { of cells }\end{array}$ & $\begin{array}{l}\text { Cell } \\
\text { type }\end{array}$ \\
\hline \multirow{3}{*}{$\begin{array}{r}\text { Jellinger } \\
(1975)\end{array}$} & $M$ & 55 & + & 10 & 58 & 116 & - & Immunoblastic & B \\
\hline & $M$ & 73 & + & 64 & 90 & 256 & - & $\begin{array}{l}\text { Immunoblastic } \\
\text { non-cleaved nuclear pattern }\end{array}$ & B \\
\hline & $M$ & 59 & + & 80 & 72 & 110 & - & $\begin{array}{l}\text { Immunoblastic } \\
\text { non-cleaved nuclear pattern }\end{array}$ & B \\
\hline $\begin{array}{l}\text { Ervin } \\
\quad(1980)\end{array}$ & - & - & $?$ & - & - & - & - & $\begin{array}{l}\text { Small cell } \\
\text { non-cleaved nuclear pattern }\end{array}$ & B \\
\hline \multirow{3}{*}{$\begin{array}{r}\text { Matsuda } \\
(1981)\end{array}$} & - & - & $?$ & 82 & 100 & 180 & - & $\begin{array}{l}\text { Immunoblastic } \\
\text { non-cleaved nuclear pattern }\end{array}$ & B \\
\hline & - & - & $?$ & 25 & 100 & 133 & - & $\begin{array}{l}\text { Immunoblastic } \\
\text { non-cleaved nuclear pattern }\end{array}$ & B \\
\hline & - & - & $?$ & 2 & 100 & 80 & - & $\begin{array}{l}\text { Immunoblastic } \\
\text { non-cleaved nuclear-pattern }\end{array}$ & B \\
\hline$\underset{(1983)}{\text { Marsh }}$ & $\mathbf{M}$ & 20 & $\mathbf{N}$ & 236 & 100 & 150 & 1.5 & $\begin{array}{l}\text { Large cell } \\
\text { cleaved nuclear pattern }\end{array}$ & $T$ \\
\hline \multirow{2}{*}{$\begin{array}{l}\text { Schmitt Graf } \\
(1983)\end{array}$} & $\mathbf{M}$ & 55 & $\mathbf{N}$ & 1191 & - & 108 & - & $\begin{array}{l}\text { Large cell } \\
\text { non-cleaved nuclear pattern }\end{array}$ & $\mathrm{T}$ \\
\hline & $\mathbf{M}$ & 24 & + & 556 & - & 182 & - & $\begin{array}{l}\text { Immunoblastic } \\
\text { non-cleaved nuclear pattern }\end{array}$ & Null \\
\hline $\begin{array}{l}\text { Ezrin Waters } \\
(1984)\end{array}$ & $\mathrm{F}$ & 72 & + & 437 & 64 & 570 & 0.5 & $\begin{array}{l}\text { Large cell } \\
\text { cleaved nuclear pattern }\end{array}$ & B \\
\hline $\begin{array}{l}\text { MGH case } \\
(1985)\end{array}$ & $\mathbf{M}$ & 49 & + & 122 & 96 & 198 & $2 \cdot 6$ & $\begin{array}{l}\text { Cleaved nuclear pattern } \\
\text { non-cleaved nuclear pattern }\end{array}$ & B \\
\hline $\begin{array}{l}\text { Hoefnagels } \\
\quad(1986)\end{array}$ & $\mathrm{F}$ & 56 & + & 9 & 30 & - & - & $\begin{array}{l}\text { Large cell } \\
\text { Cleaved nuclear pattern }\end{array}$ & B \\
\hline
\end{tabular}

$\mathrm{WCC}=$ white cell count.

palsies and two had signs of raised intracranial pressure; none had any symptoms of meningitis.

CSF cytology is an unreliable investigation with a positive yield ranging from $3-44 \%$ of cases. ${ }^{34}$ Thirteen cases of CNS-non-Hodgkin's lymphoma diagnosed by CSF immunocytology have been described (table 2). ${ }^{35-7}$ These comprise seven males, two females, and four unidentified cases with an average age of 50 years (range 14-73). The four cases presented here raise the total number of reported cases ${ }^{2}$ to 17 of whom $14(82 \%)$ had a grossly raised cell count, two $(12 \%)$ had mild lymphocytosis, and only one had a cell count within normal limits. CSF proteinosis occurred in $12(85 \%)$ cases in line with previous studies. ${ }^{4} \mathrm{CSF}$ glucose was reduced in $87 \%$ (seven of eight) in whom the investigation had been performed.

Histological studies of CNS-non-Hodgkin's lymphoma have shown a morphological distribution of $53 \%$ immunoblastic, $20 \%$ noncleaved large cell, $20 \%$ cleaved large cell and $6 \%$ small cell, and have emphasised the $B$ cell origin of this tumour. ${ }^{25}$ The four cases described here were large cell, of which one had a cleaved nuclear pattern. Overall, this changes the distribution of immunological subtypes in cytologically diagnosed CNS-non-Hodgkin's lympyhoma to $65 \%$ B cell (11 cases), $24 \% \mathrm{~T}$ cell (four cases), and $11 \%$ null (two cases). The four cases of T cell CNS-non-Hodgkin's lymphoma had no radiologically visible tumour deposits at the time of diagnosis. The clinical importance of this finding is unclear as few cases of T cell CNS-non-Hodgkin's lymphoma have been described. ${ }^{67}$

This study shows that cytological diagnosis of some lymphomas is possible before tumour deposits are detected radiologically. CSF cytology, however, is a specialised investigation and false positive results can occur with reactive processes, though the use of multiple sampling and immunohistochemical techniques increases the diagnostic reliability. ${ }^{7} \mathrm{We}$ suggest that all unexplained persistent CSF lymphocytoses should be viewed as suspicious and that efforts should be made to immunotype the cells present as earlier diagnosis would improve the prognosis of primary cerebral lymphoma.

We thank Dr R O Barnard for neuropathological advice and Mrs L Duddridge for secretarial assistance. 
1 Norman PM. CSF cytology. In: Coleman DV, Chapman PA, eds. Clinical Cytotechnology. London: Butterworths, 1989:293-302.

2 Hochberg FH, Miller DC. Primary central nervous system lymphoma. J Neurosurg 1988;68:835-53.

3 Bigner SH, Johnston WW. The cytopathology of cerebrospinal fluid[1]. Acta Cytol 1981;25:335-53.

4 Ellis SJ, Stephenson JBP, King MD, et al. Clinical justification for cerebrospinal fluid investigation. Lancet 1987 1:222-3.
5 Jellinger K. Primary Lymphoma of the CNS. Arch Neurol 1982;39:458.

6 March WL, Stevenson DR, Long HJ. Primary leptomeningeal presentation of $T$ cell lymphoma. Cancer 1988; 51:1125-31

7 Ezrin-Waters C, Klein D, Deck J, Lang AE. Diagnostic importance of immunological markers in lymphoma involving the central nervous system. Ann Neurol 1984;16:668-72.

\title{
Primary squamous cell carcinoma of the terminal ileum
}

\author{
C C Platt, N Y Haboubi, P F Schofield
}

\begin{abstract}
A case of squamous cell carcinoma of the terminal ileum with no underlying duplication or inflammatory disorder is described. The neoplasm seemed to have originated from the surface epithelium, invading the wall and metastasising to the regional lymph nodes. The 65 year old patient was free of disease three years after having had the tumour removed.

Previous reports of squamous carcinoma of the small intestine have been associated with intestinal duplication or metastatic disease from distant sites.
\end{abstract}

\section{Case report}

A 62 year old man was admitted to hospital with a 12 month history of intermittent midabdominal colic and vomiting. A barium enema performed as an outpatient before admission showed an extrinsic filling defect in the caecum. No reflux of barium into the terminal ileum was shown. A computed tomogram of the abdomen showed an homogeneous lobulated mass in the right iliac fossa which seemed to affect small bowel loops. There was no evidence of metastatic deposits in the liver. A chest $x$-ray picture, routine biochemical tests, and blood count were within normal limits.

At laparotomy, a tumour was found arising from the terminal ileum, with enlarged nodes in the ileocaecal region. There was no other evidence of intra-abdominal disease. A resection of the terminal ileum with a limited right colectomy was carried out to remove all macroscopic disease. Intestinal continuity was restored by end to end anastomosis. The patient made an uneventful recovery and was alive and well three years later with no evidence of recurrence.

\section{Pathology}

The resected specimen consisted of $40 \mathrm{~cm}$ of small intestine, the appendix, and $10 \mathrm{~cm}$ of large bowel with the associated mesentery. There was a fungating tumour sparing the terminal $5 \mathrm{~cm}$ of ileum but affecting the mucosa of the next $5 \mathrm{~cm}$ and spreading through the thickness of the wall into the mesentery. Focal areas of calcification were identified on cut section.

Paraffin wax sections showed the tumour to be a moderately differentiated keratinising squamous cell carcinoma arising from the surface epithelium. Intercellular bridges and keratinous cysts and pearls were prominent (figure). The tumour had infiltrated the wall and extended into the mesentery and paraintestinal lymph nodes. There was evidence of vascular invasion, but none of glandular differentiation or adenomatous change in any part of the tumour.

Mucin stains and Gremelius argyrophil stains were negative. Electron microscopical examination showed features typical of squamous cell differentiation. The neoplastic cells contained well formed tonofilaments, while microvilli, glycocalyceal bodies; mucinous granules were absent.

\section{Discussion}

The spread of tumour into the small bowel as a result of secondary squamous carcinoma has been well documented. ${ }^{1-3}$ Primary malignant tumours, however, are rare and the squamous carcinomas have so far been reported in cases of duplication. ${ }^{4}$

In the colon squamous cell differentiation is seen in about $0.05 \%$ of adenocarcinomata ${ }^{5}$ and in $0.4 \%$ of adenomata. ${ }^{6}$

The pathogenesis of squamous cell carcinoma of the colon is unknown but in some cases it has been associated with carcinoma 